Pamiętnik Literacki 2021, 2, s. 89-109

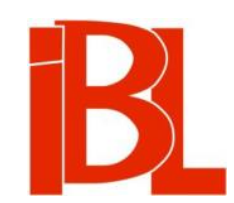

\title{
Wielka Dama Oświecenia. Księżna Izabela Czartoryska w blasku teatru,teatralizacji i mediów
}

\author{
Irena Kadulska
}


Pamiętnik Literacki CXII, 2021, z. 2, PL ISSN 0031-0514

DOI: $10.18318 / \mathrm{pl} .2021 .2 .7$

IRENA KADULSKA Uniwersytet Gdański

\title{
WIELKA DAMA OŚWIECENIA KSIĘŻNA IZABELA CZARTORYSKA W BLASKU TEATRU, TEATRALIZACJI I MEDIÓW
}

\begin{abstract}
Wiersz na Dzień Wielkich Imienin Księżny Izabeli Czartoryskiej z okoliczności otworzenia pierwszy raz $w$ tenże sam dzień teatrum polskiego, pióra Józefa Bielawskiego, fligel-adiutanta buławy wielkiej litewskiej ${ }^{1}$, został ofiarowany solenizantce w formie wolantu 19 XI 1765:
\end{abstract}

\footnotetext{
Przyjm, Wielka Księżno, do rąk to pisanie Któreć ma Muza niesie na wiązanie, I pozwól, aby dzień Twego imienia Był hasłem do scen polskich otworzenia; I tym się bardziej w ojczyźnie swej wsławił, Że pierwszy widok Warszawie wystawił. Co Cię Elżbieto stąd czeka za chwała, Gdy o tym będzie potomność wiedziała; Ty, której wielkość nie tak [z] urodzenia, Jako [z] cnót godna tego przeznaczenia, I której pamięć wtenczas chyba zginie, Kiedy już Wisła z swych źrzódeł wypłynie. Czy mógłżem więcej w mym pokornym stanie Nad nieśmiertelność dać Ci na wiązanie? ${ }^{2}$
}

1 Zob. T. Kantelecka, T. Kostkiewiczowa, Józef Bielawski (1739-1808). W zb.: Pisarze polskiego oświecenia. Red. T. Ko stki ew i z owa, Z. Goliński. T. 1. Warszawa 1992. Ocena komediopisarstwa Bielawskiego także w: D. Ra taj c za k ow a, Komedia oświeconych. Warszawa 1991, passim.

2 J. Bi e law s k i, Wiersz na Dzień Wielkich Imienin Izabeli Czartoryskiej [...]. Drukarnia Mitzlerowska. Warszawa 19 XI 1765. Informacja o druku w: L. Berna cki, Teatr, dramat i muzyka za Stanisława Augusta. T. 2: Notatki i studia. Lwów 1925 (przedruk typograficzny: 1979), s. 382. Tekst cyt. za: J. J a c k 1, Litteraria. W zb.: Teatr Narodowy 1765-1794. Red. J. K o tt. Oprac. J. J a ck1 [i in.]. Warszawa 1967, s. 346.

Zob. też imieninowe gratulacje dla księżnej pióra F. Karpińskiego (Do Jaśnie Oświeconej Księżny JejMci Izabeli z Flemingów Czartoryskiej, jenerałowej ziem podolskich, $w$ dzień imienin jej) i F. D. Kn i aźn in a (Do księżny) w zb.: Wiersze imieninowe poetów z drugiej połowy XVIII wieku. Wstęp, wybór, oprac. B. Wolska, B. Mazurkowa, T. Cha chulski. Warszawa 2011. Zob. ponadto: Wiersze Józefa Koblańskiego i Stanisława Szczęsnego Potockiego - zapomnianych poetów oświecenia. Wybór, przygot. tekstów, wstęp, koment. E. Aleks an drow s ka. Wrocław 1980. Świat poprawiać - zuchwałe rzemiosło. Antologia poezji polskiego oświecenia. Oprac. T. Ko stkiewiczowa, Z. Goliński. Warszawa 1981 (wiersze F. D. Kniaźnina, F. Dzierżykraja Morawskiego i innych poetów). - Czartoryscy. Wiersze poświęcone rodowi Czartoryskich na łamach „Zabaw Przyjemnych i Pożytecznych”. Edycja krytyczna ze wstępem. Wstęp, oprac. M. P a w la ta. 
Ów listopadowy dzień - zakończony prześwietna imieninową fetą „najznakomitszych osób królewskiego Domu”: trzech Wielkich Elżbiet związanych ze Stanisławem Augustem - był zarazem dniem dramaturgicznego debiutu autora powinszowania ${ }^{3}$. Wystawienie jego komedii Natręci w Operalni Saskiej przed premierową publicznością, przepełniająca $\mathrm{w}$ „nadzwyczajnym ścisku wszystkie piętra, zakamarki i przedsionek teatru”, zapoczatkowało dzieje Teatru Narodowego („Król był ojczystej sceny zaprowadzenia twórcą"4), wpisanego przez monarchę w program reformowania Rzeczypospolitej ${ }^{5}$. Ogromnego zainteresowania i aspiracji widzów nie zmniejszyła informacja o płatnych biletach, która pojawiła się po raz pierwszy na polskim afiszu teatralnym ${ }^{6}$.

Królewski wymiar uroczystości podkreśliły wersy Prologu z okoliczności otworzenia pierwszej komedii polskiej, recytowane w części inaugurującej spektakl przez Talię, muzę komedii, zstępującą na scenę z siedziby Apollina ${ }^{7}$. Już w tym momencie podniesione w górę żyrandole jaśniały blaskiem lamp, oświetlających kilkukondygnacyjną widownię oraz scenę, wyposażoną w stosowną dekorację, prezentującą w prologu Parnas, który stał się pierwszym, uszlachetniającym planem wystawienia, w akcie III zaś wyobrażająca przyległy bezpośrednio do teatru Ogród Saski, dobrze znany stołecznej publiczności ${ }^{8}$. Była to „unarodowiona” zmiana w stosunku do oryginału Moliera, sytuującego akcję w paryskim Ogrodzie Luksemburskim $^{9}$. W zasobach Operalni nie było kompletu kulis o tej tematyce, dlatego

Red. nauk. B. Wolsk a. Łódź 2011 (wiersze K. N. Sapiehy, A. Naruszewicza, A. Korwin Kossakowskiego, G. Piramowicza, F. Oraczewskiego).

3 Trzy Elżbiety to: Branicka z Poniatowskich, Czartoryska z Flemmingów, Lubomirska z Czartoryskich. Opis ich relacji z królem w: T. Ko st ki ew i c z ow a, Pamiętniki Stanisława Augusta na nowo odkryte. Warszawa 2015, s. 64-69. Opis premiery w: „Wiadomości Warszawskie” 1765, nr 88, z 20 XI. Przedruk w: J. J a c k 1, Teatr iżycie teatralne w gazetach igazetkach pisanych (1763-1794). W zb.: Teatr Narodowy 1765-1794, s. 466-469. Elżbieta Czartoryska przyjęła imię swej prababki, Izabeli z Morsztynów Czartoryskiej - zob. A. A l e k s a n d r o w i c z, Izabela z Flemmingów Czartoryska (1746-1835). W zb.: Pisarze polskiego oświecenia, t. 3 (1996), s. 609-638. - Z. W oj t k o ws k a, Saga rodu Czartoryskich. Pomoc researcherska J. Pi a s e c k a. Warszawa 2020, s. 171-199. W. B o gu sła w s ki, Dzieje Teatru Narodowego na trzy części podzielone oraz Wiadomość o życiu sławnych artystów [...]. Cz. 1. Warszawa 1820 (wyd. fotooffsetowe, z posłowiem S. W. B a li c ki e g o: Warszawa 1965), s. 1.

5 Zob. M. Kli m ow i c z: Kształtowanie się i źródła polskiej doktryny teatralnej w latach 1765-1767. „Pamiętnik Literacki” 1963, z. 3; Dramat modernizacji I Rzeczypospolitej $w$ teatrze polskiego oświecenia. W zb.: Teatr Narodowy $w$ służbie publicznej. Marzenia i rzeczywistość. Praca zbiorowa pod kier. A. Kuligowskiej-Korzeniewskiej. Warszawa 2007. - K. Wierzbicka-Michals ka, Teatr $w$ Polsce $w$ XVIII wieku. Warszawa 1977, s. 77-80.

6 Afisz teatralny Natrętów w: Ber n a cki, op. cit., t. 2, s. 10. Zob. też P. Ką kol, O teatrze zawodowym w osiemnastowiecznym Gdańsku. Wokót gdańskiego afisza. Gdańsk 2009, s. 157-217.

7 Podobnie brzmi anons reklamowy Natrętów w „Suplemencie” do „Gazety Warszawskiej” z 19 III 1766: „Komedia najpierwsza z polskich grana na teatrum JKMci [...]”- zob. S. Grze szczuk, D. H o m bek, Ksiażka polska w ogłoszeniach prasowych XVIII wieku. Źródła. T. 4, cz. 2. Red. Z. Golińs ki. Kraków 2000, poz. 7192.

8 Zob. B. Król-Ka czorows ka, Teatr dawnej Polski. Budynki, dekoracje, kostiumy. Warszawa 1971, s. 75-76. - Z. Ra s ze w s ki, Krótka historia teatru polskiego. Warszawa 1977, s. 59-64.

9 Zob. Bogusławski, op. cit., cz. 1, s. 2. - Ratajczakowa, op. cit., s. 60-74. - A. Kuligows k a - K o r z e n i e w s k a, Dwieście czterdzieści lat Teatru Narodowego (1765-2005). Wstęp w zb.: Teatr Narodowy $w$ służbie publicznej, s. 6. 
Szymon B. Zug przygotował na premierę nowy, „warszawski”, zestaw dekoracji, oddających klimat stolicy ${ }^{10}$.

Synchronia miejsca scenicznego $\mathrm{z}$ miejscem realnym i $\mathrm{z}$ warszawską metaforyka dedykowanego królowi Prologu oraz ze stołecznymi aluzjami imieninowego wiersza dla Czartoryskiej służyła wyrazistości i zespoleniu komunikatu scenicznego $z$ rzeczywistością zewnętrzną. Zwracała uwage zarówno na „Najjaśniejszego i Najpotężniejszego Pana Stanisława Augusta”, jak też na sytuację jego uroczystego przejazdu ulicami stolicy, na aplauz szpalerów mieszkańców oraz na stłoczonych widzów obecnych w teatrze, a także na adresatkę imieninowego wiersza - Izabelę Czartoryską, w ten sposób wyróżnioną oficjalnie i towarzysko, która już od tego momentu będzie obiektem stałego zainteresowania publiczności ${ }^{11}$. Wygłoszenie laudacji w miejscu publicznym wobec szerokiego audytorium nadało pochwale wysokie znaczenie. Po wystawieniu komedii „Z powszechną od przytomnych spektatorów pochwałą" 12 nastąpił powrót do bezpośredniej gloryfikacji panującego Stanisława Augusta w Epilogu rzeczonym przez aktora po otwarciu teatrum polskie$g o^{13}$. Z kolei muza poezji, w sposób równie zaszczycający, skierowała swą deklamację do Izabeli, mianując ją patronką otwarcia narodowej instytucji kultury i wieszcząc dar nieśmiertelności (nie można wykluczyć, że Bielawski przepowiadał ten dar raczej sobie, marząc, iż zostanie uwieńczony laurem poetyckim ${ }^{14}$ ). Od tej premiery nazywano Czartoryską opiekunką sztuki scenicznej, „nad którą polskie theatrum nie ma większej protektorki” 15 - jak napisał w dedykacji tłumacz francuskiej komedii Jeana-François Regnarda Demokryt (1775). Podobnym tonem brzmi dedykacja ofiarowanego księżnej przekładu rosyjskiego dramatu Prześladowanie $(1778)^{16}$. Literaci wskazywali także jej mecenat i patronat nad powstaniem utworów oraz nad ich realizacjami teatralnymi; tu szczególnym przykładem są inspirowane przez nią osiągnięcia dramaturgiczne Franciszka Dionizego Kniaźnina.

Słynny inauguracyjny spektakl wyróżniło znaczenie dla kultury ${ }^{17}$, wprowadzenie polskiej wersji francuskiego oryginału i zespolenie mediów scenicznej prezentacji w spektakl o charakterze historycznym ${ }^{18}$. Było to doświadczenie dane po

Zob. B. Król-Ka c z or ow s ka: Oprawa plastyczna widowisk $w$ teatrze polskiego oświecenia (dekoracje i kostiumy). W zb.: Teatr Narodowy $w$ dobie oświecenia. Księga pamiatkowa sesji poświęconej 200-leciu Teatru Narodowego. Wrocław 1967, s. 207-209; Teatr dawnej Polski, s. 123. Zob. Wierzbicka-Michalska, op. cit., s. 272. - Aleksandrowicz, op. cit., s. 609. M. Rut k ow s ka, Terminologia dramatu i teatru $w$ polskim oświeceniu. Poznań 2007, s. 645. „Wiadomości Warszawskie” 1765, nr 88, z 20 XI; Cyt. za: Ka n tele c ka, Ko s t ki e w i c z o wa, op. cit., s. 513.

13 Epilog [...]. W: J a c k1, Litteraria, s. 347-348.

14 Zob. J a c k1, Litteraria, s. 346, przypisy 1-2.

15 Tłumaczenie XX Pijarów - zob. Bern a c ki, op. cit., t. 2, s. 222.

16 Tłumaczem był M. Karendowic, „oficer w wojsku rosyjskim zostający” - zob. ibidem, s. 293.

17 Zob. J. C i e c h ow i c z, Jak możliwa jest historia teatru. W zb.: Jak badać teatr. Materiały z konferencji metodologicznej poświęconej badaniom historycznoteatralnym, Kraków, 28 września 2002. Red. M. D ę b ow s ki. Kraków 2003. - M. D ę b ow s ki, Pamięć teatru. W zb.: jw.

18 Przyjmujemy szerokie oświeceniowe definiowanie teatru: przedstawienie, reprezentacja, spektakl, spektakulum, teatron, teatrum, widok, widowisko, wystawienie - zob. Rutkowska, op. cit., s. 543-561. Pojęcie teatralizacji omawiają: D. Ra t a j c za k ow a, Galeria gatunków widowiskowych, teatralnych i dramatycznych. Poznań 2015, s. 13-29, 266-270. - K. B r a u n, Teatralizacja: po- 
królewsku, do którego Czartoryska - adresatka premiery, powróci 20 lat później w swoim książęcym teatrze w Puławach. W warszawskim wczesnym repertuarze znacząca jest też typowość sztuki: synchronia żywego słowa i stosownych mediów wizualnych. Połączenie nośników komunikowania $z$ charakterystycznymi dla teatru środkami przekonywania tworzyło medialność widowiska, obliczonego na reakcje zróżnicowanej stanowo publiczności, zespolonej sytuacją wspólnego odbioru ${ }^{19}$. O reakcjach widzów mówili zarówno saski agent Johann Christoph Heine, jak i sam Bielawski - ten ostatni ustami bohaterów komedii Dziwak, wystawionej rok później $^{20}$. Premiera Natrętów podobała się także damom - księżna Maria z Lubomirskich Radziwiłłowa pisała w listach o swym najwyższym podziwie dla aktorów, dodając, iż „pierwsze to przedstawienie zgromadziło ogromna publiczność” 21 . Dostrzeżenie zróżnicowania społeczności odbiorców w spektaklu premierowym stało się dla Czartoryskiej wartością ukierunkowaną na przyszłość. W późniejszej działalności ujawni się jej umiejętność inspirowania i tworzenia nowych form oraz sposobów komunikowania, a także upowszechniania treści historycznych, patriotycznych i moralnych, coraz bogatszych środków wypowiedzi i przekazu. Znaczenie powołania Teatru Narodowego rozpatrzymy również z perspektywy osoby niechętnej przedsięwzięciu - szpiega Johanna Heinego, administratora Pałacu Saskiego. Jego raporty są relacją osobną, nie mającą związku ze społecznością widzów, pozostają jednak źródłem uznawanym za wiarygodne. Mimo niechęci, dostrzegł on, jak już wspomniano, dobra gre zespołu i powszechne zadowolenie publiczności. Donosił o wydarzeniu w swych raportach oraz listach, rozważając zadania i możliwości przyszłego oddziaływania publicznej instytucji kultury ${ }^{22}$.

granicze życia i teatru. „Tematy i Konteksty” nr 7 (2017), s. 46-57. Terminy: „medium” i „multimedium" rozpatrujemy w oparciu o badania przedstawione w pracy E. Kotarskiego Kultura medialna średniowiecza. Europa łacińska (Warszawa 2017, s. 14-15, 263-280). Autor pisze: „Media jako nośniki informacji i wartości miały i mają swoje miejsce w kulturze, kreują bowiem dobra kultury, rozpowszechniaja je. [...] Media zachowują zdolność tworzenia nowych jakości, nowych wartości kształtujących kulturę" (ibidem, s. 14).

19 Zob. K. D mit r u k, Problemy publiczności literackiej $w$ dawnej Polsce. W zb.: Publiczność literacka i teatralna w dawnej Polsce. Red. H. Dzi e c h c ińs k a. Warszawa 1985, s. 37-39. - K o tar s ki, op. cit., s. 7-20. - M. Pa r kit ny, Nowoczesność oświecenia. Studia o literaturze i kulturze polskiej drugiej połowy XVIII wieku. Poznań 2018, s. 58-59, 62-64.

20 J. Ch. He in e, Raporty szpiega saskiego. W: W. Zaw a d z ki, Teatr we wspomnieniach i listach. W zb.: Teatr Narodowy 1765-1794, s. 635-639. Jest to przedruk obszernych fragmentów z wyd.: J. Ch. He in e, Teatr Narodowy 1765-1766. Raporty szpiega. Przeł., oprac. M. Kli mowicz. Wstęp Z. Ras zewski. Warszawa 1962. Wersja zdigitalizowana wydania z r. 1962 w: Cyfrowa Biblioteka Narodowa Polona. Korzystamy tu zarówno z przedruku Zawadzkiego, jak i z tekstu w cBN Polona oraz z fragmentów czy cytatów znajdujących się w pracach badaczy oświecenia, za każdym razem zaznaczając, na jakim źródle się opieramy.

Wpływ premiery na publiczność był zaskakująco silny, natychmiast zapamiętywano role aktorów, np. podczas drugiego wystawienia Natrętów (21 XI) - jak pisze A. Ma gi e r (Estetyka miasta stotecznego Warszawy. Wrocław 1963, s. 257-258. Cyt. za: Z aw a d z ki, op. cit., s. 644) - „zasłabła aktorka. Spośród publiczności zgłosił się "jeden z dworskich hetmana Branickiego", który oświadczył, że komedię, widzianą poprzednio, zna na pamięć i zastapi chorą aktorkę. Ubrano go w kobiece suknie, a że był śliczny chłopiec, odegrał rolę z powszechnym aplauzem".

21 M. Radziwiłł ow a, listy do hetmana J. K. Branickiego i do ks. A. W. Betańskiego, z 20 XI 1765. Cyt. za: Bernacki, op. cit., t. 2, s. 383.

H e in e, Raporty szpiega saskiego (w: Z a w a d zki, op. cit.). 
Pragnienie uświetnienia dnia 19 listopada premierowym spektaklem można uzasadniać obchodzoną właśnie uroczystością rodzinną: na dzień ten przypadała bowiem, oprócz imienin Elżbiety - Izabeli Flemminżanki, czwarta rocznica jej ślubu z księciem Adamem Kazimierzem Czartoryskim, generałem ziem podolskich ${ }^{23}$. Należał on, podobnie jak król, do grona współtwórców projektu polskiego teatru, w którym to projekcie brali udział Ignacy Krasicki oraz inni członkowie fundacji w tym celu założonej ${ }^{24}$. Na kilka miesięcy przed premierą książę, w apartamentach Pałacu Błękitnego, przygotowywał do występu w Natrętach debiutujący polski zespół aktorski ${ }^{25}$. Czartoryscy rozpoczęli w tej warszawskiej siedzibie prestiżowa działalność - wspólny mecenat nad sztukami pięknymi ${ }^{26}$. Księżna Izabela była protektorką, obserwatorką, a może również uczestniczką tej szkoły aktorstwa scenicznego. Książę Adam także doskonalił tekst pierwszej polskiej komedii, przypuszczalnie wraz z wierszami dedykacyjnymi dla króla i księżnej. Jego własna twórczość dramaturgiczna, obok rozważań teoretycznych o sztuce scenicznej, przyczyniła się do powstania w kręgu rodzinnym przyjaznej aury dla sztuki teatru. Wpływała na zainteresowanie księżnej repertuarem scenicznym Szkoły Rycerskiej, wystawiającej polskie komedie księcia Adama oraz dramaty w języku francuskim. Zadaniem i funkcją teatru było tu „udoskonalenie człowieka”. Jako osoby zaprzyjaźnione ze środowiskiem Szkoły „księżna Czartoryska i księżna marszałkowa Lubomirska prezentowały kadeckim aktorom, jak mają odgrywać role kobiece”27. Pamiętnikarze, a wśród nich Julian Ursyn Niemcewicz, ze szczególną estymą wspominają uroczyste wystawienie Panny na wydaniu: „w styczniu 1771 r. na scenie pojawiły się damy i kawalerowie $z$ otoczenia Stanisława Augusta jako aktorzy"28. Niewątpliwie w tej szczególnej obsadzie aktorskiej nie zabrakło Izabeli Czartoryskiej. Mimo zamknięcia w r. 1773 sceny kadeckiej korespondenci ukazujacych się w Warszawie (i w innych miastach) „gazetek” rejestrowali obecność księżnej podczas kolejnych uroczystości Szkoły ${ }^{29}$. Jak już wspomniano, wspólne zaangażowanie małżonków Czartoryskich będzie po latach inspirowało ich puławsko-sieniawskie inscenizacje ${ }^{30}$.

Zob. Aleks androwicz, op. cit., s. 609-610.

Zob. M. Klim ow i c z, Poczatki teatru stanisławowskiego. Warszawa 1965, s. 15-17. T. J. Pokrzywniak, wstęp w: Komedie Ignacego Krasickiego. Poznań 1994. - I. Ka duls ka, Ignacy Krasicki do publiczności polskiego teatru. „Słupskie Prace Filologiczne. Seria Filologia Polska” 2002, nr 1, s. 9-15.

Zob. He in e, Raporty szpiega saskiego (w: Zawa dzki, op. cit.), s. 632. - Wi e r zbicka-Michals ka, op. cit., s. 87.

Zob. Z. Lib e ra, Problemy polskiego oświecenia. Kultura i styl. Warszawa 1969, s. 204.

A. F r a n k e, Teatr Korpusu Kadetów - kilka uwag. W zb.: Kajety Korpusu Kadetów Szkoty Rycerskiej. Ludzie - wartości-kultura materialna. Red. nauk. E. Wich row ska, A. Wd owik. T. 2. Warszawa 2019, s. 527-528.

Ibidem, s. 528-529.

Gazety pisane i informacje tygodniowe $z$ Warszawy, wyjatkowo $z$ innych miast [...] (28 II 1781 datacja według E. Rabowicza). Bibl. Jagiellońska, rkps 6799 II. Cyt. za: K. Maksimowicz, Refleksja nad życiem, kondycją ludzka i sensem egzystencji: „Do Ignacego Potockiego, pisarza lit[ewskiego], po śmierci żony jego, Elżbiety z ksiażat Lubomirskich”. W zb.: Czytanie Karpińskiego. Red. B. Mazurkowa, T. Chachulski. T. 1. Warszawa 2017, s. 311-314.

Zob. Z. Zahrajówna, wstęp w: A. K. Czartoryski, Komedie. Oprac. Z. Zahrajówna. Warszawa 1955. - J. Pe zd a, Przeszłość przyszłości. Historia zbiorów rodzinnych opowiedziana przez Władysława Czartoryskiego. „Rocznik Biblioteki Naukowej PAU i PAN” t. 58 (2013), 
Dodajmy też, że bezpośrednia edukacja sceniczna - aktorska - Izabeli rozpoczęła się wcześniej, przed dedykowana jej listopadową premierą. Odkrycie kreatywnej magii kostiumu i sprawczej siły „przyjmowania roli” wiązało się z przeżyciami na trasie poślubnego wojażu małżonków Czartoryskich. 16-letnia księżna włożyła na czas podróży mundur oficera regimentu księcia generała, co było wejściem w świat zabawy i „zamazywaniem tożsamości” ${ }^{31}$. Droga paradnego orszaku nowożeńców wiodła przez Frankfurt nad Menem, gdzie oczekiwano wówczas młodego króla Danii, mającego się udać do nadreńskiego kurortu. Władze miasta wraz z mieszkańcami, widząc wszystkie ikoniczne sygnały przybycia gościa, czyli wspaniałość wjeżdżającej świty oraz osobę „młodzieńca” w mundurze, przypominajacego figura i delikatnością duńskiego króla, rozpoczęły uroczystość powitania władcy. Podniosłe mowy i hołdy zwierzchności municypalnej, aplauz rzeszy mieszkańców, gra orkiestr wojskowych, iluminacje - cały ten splendor kierowano do Izabeli, która w swym ukostiumowaniu stała się dla zgromadzonych „königliche Majestät”. W tym spektaklu uroczystego „wjazdu” jakiekolwiek wyjaśnienia nie odnosiły skutku, gdyż obywatele-odbiorcy byli przekonani o autentyczności całej akcji ${ }^{32}$. Kulminacja powitania nastapiła w chwili, gdy z tłumu wyszła piękna dziewczyna i padłszy do nóg „króla Danii” przedstawiła swą rozpaczliwą suplikę w sprawie służącego w wojsku duńskim brata. Teraz już świat na placu we Frankfurcie musiał bezwzględnie wrócić do swego porządku. Izabela weszła do komnat, zdjęła mundur (przebranie? już kostium do roli?) i włożyła piękną balową suknię, co w sposób naturalny, wizualnie, wyjaśniło i zakończyło kłopotliwą sytuację. Mieszkańcy zrozumieli, a prośba pięknej dziewczyny dotarła za pośrednictwem księżnej do adresata i została spełniona. Tę narrację o pierwszej roli Izabeli przypomniał, na podstawie jej pamiętników, Ludwik Dębicki - monografista Puław. Dodał też, że podobny scenariusz miał miejsce w nieodległej Moguncji ${ }^{33}$. Relacja z tych wydarzeń wskazywała znaczenie wykonawcy, kostiumu i publiczności, czasu i miejsca akcji podstawowych elementów teatru.

Wracając do wczesnych warszawskich występów scenicznych księżnej, chcemy przywołać jej ważniejsze role w teatrze świata i sceny, dzięki którym zbudowała fenomen swej artystycznej osobowości i talentu.

Już 17 I 1765 Izabela Czartoryska pojawiła się u boku małżonka na scenie warszawskiego teatru wojewody Michała Kazimierza Ogińskiego w komedii uświetniającej urodziny króla. Występowi towarzyszył koncert na dwoje skrzypiec i flet,

s. 112-127. - D. St a n is ł a w c zy k, Twórczość dramatyczna Adama Kazimierza Czartoryskiego. Red. nauk. W. Wa le c ki. Kraków 2013. - E. W i c h r ow s ka, wstęp w zb.: Kajety Korpusu Kadetów Szkoły Rycerskiej, t. 2.

31 J. Ryba, „Maskarady architektoniczne”. W zb.: Literatura-historia-dziedzictwo. Prace ofiarowane Profesor Teresie Kostkiewiczowej. Red. T. Cha chulski, A. Grześ k owiak-Krwawicz. Warszawa 2006, s. 388-389.

32 Zob. J. Li mon: Aktorzy. W: Między niebem a sceną. Przestrzeń i czas $w$ teatrze. Gdańsk 2002, s. 213-217; Piąty wymiar teatru. Gdańsk 2006, s. 13-30. - W. D u dzi k, Karnawały w kulturze. Warszawa 2005, s. 103-115.

33 L. D ę b i c ki, Puławy 1762-1830. Monografia z życia towarzyskiego, politycznego i literackiego na podstawie archiwum $k s$. Czartoryskich $w$ Krakowie. T. 1: Czasy przedrozbiorowe. Lwów 1887, s. 92-96. Cyfrowa Biblioteka Narodowa Polona. 
a po spektaklu i uroczystej kolacji „strzelano z dział, "puszczano rakiety i kule świetlne " 34 . Wkrótce, w marcu, grała (obok księcia) rolę amantki w komedii $\mathrm{z}$ repertuaru Comédie Française. Była to okolicznościowa gala w pałacu księcia Aleksandra Sułkowskiego z okazji imienin Kazimierza Poniatowskiego - podkomorzego koronnego, królewskiego brata ${ }^{35}$. Podniosły charakter fety podkreślono biciem $\mathrm{z}$ armat i nocnym pokazem fajerwerków. Zwykle podczas takich uroczystych imprez towarzyskich wzmacniano przekaz dramatyczny środkami artystyczno-widowiskowymi, tj. efektami wokalno-muzycznymi i akustycznymi (najczęściej salwami, artyleryjską kanonadą) oraz dynamiką sztuki ogniowej - barwnymi fajerwerkami i świetlnymi napisami na tle wieczornego nieba ${ }^{36}$. Innym rodzajem spektakli prywatnych były wieloelementowe festyny - teatralizacje „pod obłokiem”, w których uczestnicy, zachowując swój magnacki status, wykonywali czynności odbiegające od ich codziennego rytuału. Teatralizacje plenerowe zwyczajowo obejmowały zaszczycające przybycie, uroczysty posiłek (np. „in Templo Dianae”), aktorskie odśpiewanie kantat „w duchu russowskim”, przejazdy gości-uczestników gondolą wiślaną i spacery do wsi, w których celebrowano wesela chłopskie $z$ muzyka, tańcami, konkursami. Przykładowo, w sierpniu 1765 król, jako główny widz i uczestnik plenerowego widowiska, przybył do Młocin w towarzystwie dam, prowadząc Izabelę w pierwszej parze ${ }^{37}$. Festyn-teatralizacja składał się z kolejnych dworsko-wiejskich części. Nie można wykluczyć wpływu schematów tych widowisk na podobne inscenizacje organizowane po latach przez Czartoryską na Kępie w Puławach. Rysunki Jana Piotra Norblina de la Gourdaine z 1802 r. utrwaliły wspólną zabawę gości, domowników i okolicznych mieszkańców w rzeczywiste życie wiejskie (zwózka żyta, praca w kuźni, pranie, przędzenie, rąbanie drew). Brak tam natomiast elementów dworskiej galanterii, takich jak opera, koncert ukrytej kapeli, powitanie bogini Hebe i antycznych Gracji, etc. Zabawa na Kępie w gospodarstwo, jako teatralizacja wiejskich zajęć, była autentycznym sąsiedzkim spotkaniem mieszkańców pałacu z wieśniakami, mającym duże znaczenie społeczne ${ }^{38}$.

Od chwili uroczystego otwarcia sceny narodowej uwyraźnia się w działaniach Izabeli Czartoryskiej, jak już stwierdzono, aktywna więź ze sztuką teatru. Towarzyszyła tej postawie dobra relacja $z$ wykonawcami, poświadczona później koleżeńską wręcz pamięcią o świecie aktorskim tamtego czasu. Po latach, w listach do córki, Marii Wirtemberskiej, Izabela wspomina z uśmiechem (i z ploteczkami o makijażu madame Sophie Leuiller i innych) prywatne spotkania $z$ artystami z zespołu włowidowiskowych, teatralnych i dramatycznych, s. 23-25. - B ra u n, op. cit., s. 47, 52.

Kli m ow i c z, Początki teatru stanisławowskiego, s. 24. Klimowicz cytuje tu list J. Ch. H e in e go z 23 I 1765 (Bibl. Polska w Paryżu, rkps 57). Zob. Kli m o w i c z, Poczatki teatru stanisławowskiego. - J a c k 1, Teatr i życie teatralne w gazetach i gazetkach pisanych (1763-1794), s. 454.

Zob. I. Kadulska, Magia ogni kunsztownych $w$ spektaklach plenerowych XVIII wieku. W zb.: Oświecenie nieoświecone. Człowiek, natura, magia. Red. D. Kow a lew s k a, A. Roć k o, F. W olański. Warszawa 2018, s. 99-114. - A. Norkowska, Miasto w piśmiennictwie polskiego oświecenia. Bydgoszcz 2019, s. 260-290.

Zob. Klim 
skiego w pałacu w Wilanowie oraz ujmujące zachowanie antreprenera teatralnego, Karola Tomatisa ${ }^{39}$. Ta zażyłość skłania do zastanowienia, czy wcześniejsze doświadczenia teatralne księżnej miały wpływ na Czartoryską-aktorkę, zaangażowaną na krótki czas do zespołu przygotowującego premierę Natrętów. Heine komunikował w liście z 16 X 1765: „Musiała jednak zmienić nazwisko na Czartyńska, inaczej nie otrzymałaby miejsca ani roli" ${ }^{40}$. Mieczysław Klimowicz opatruje ten list uwagą, że nazwisko księżnej nie pojawia się ani razu w źródłach teatralnych tego okresu. Nazwisko jej zapisano w formie: „Czartyńska”, nie podając imienia. Kwestię tę zarejestrował jedynie Heine ${ }^{41}$. Dalej saski szpieg powściągliwie ujawnia, iż aktorka pochodziła $z$ „Sacra Familia” i $z$ tego powodu zmienione nazwisko szybko zniknęło ze spisów. Milczenie skrywa jej emploi, imię i pełną tożsamość. Przyjęcie supozycji, iż ową aktorką była 19-letnia Izabela, która pragnęła wystąpić w spektaklu inauguracyjnym, lecz napotkała zrozumiały opór rodziny, pozwoliłoby wyjaśnić, dlaczego spośród trzech Elżbiet tylko jej dedykowano przedstawienie, a także poznać powód opuszczenia wielkiej fety przez urażoną królewską siostrę - Elżbietę Branicką, trzecią Wielką Elżbietę ${ }^{42}$.

Kolejne reprezentacje Teatru Narodowego umożliwiały bywalcom stałą obserwację zarówno wykonawców, jak i całego audytorium (którą ułatwiało oświetlenie w czasie spektaklu po obu stronach rampy), oraz publiczną ocenę ${ }^{43}$. Ujawniła się też różnorodność reagowania na przyjemność, połączoną z pożytkiem, oferowaną $\mathrm{w}$ przedstawieniach przez teatr ${ }^{44}$. Uczestnictwo jako wartość przypisana do scenicznych występów $z$ wolna kierowało uwagę księżnej na aktorskie sposoby prezentowania, na ekspresję, wspomagająca perswazyjność wygłaszanych treści. Łączyło się to $\mathrm{z}$ refleksją Czartoryskiej nad wyglądem, przekonującym do wypowiadanych słów, $\mathrm{z}$ korygowaniem swojego realnego wizerunku $\mathrm{w}$ przygotowaniu do „roli w teatrze życia”, wynikało ze związków z teatrem, ale też z modelowania własnej osoby zgodnie ze sztuką portretową ${ }^{45}$. Przygotowaniem do scenicznych ról i dobre-

Zob. Korespondencja rodzinna. Listy do Marii z Czartoryskich Wirtemberskiej od matki Izabeli. 1784-1800. Cyfrowa Biblioteka Narodowa Polona. Bibl. Czartoryskich, rkps 6137 II, k. nlb. (list pisany z Puław): „Tomatis i Pani Tomatis wraz z innymi domownikami bywali w Wilanowie u księcia wojewody, który lubił Włochów "gdzie pamiętam, że Tomatis dawał mi praliny"”.

Cyt. za: Kli mow i c z, Poczatki teatru stanisławowskiego, s. 163.

Zob. ibidem.

42 Zob. He in e, Teatr Narodowy 1765-1766. Raporty szpiega (cBN Polona), s. 10. - Kli mo w ic z, Poczatki teatru stanisławowskiego, s. 163, 314. - Stownik biograficzny teatru polskiego 1765-1965. Warszawa 1973, s. 108. Braniccy, zainteresowani spektaklem, otrzymali listowne sprawozdanie od ks. Marii z Lubomirskich Radziwiłłowej. Zob. też P. Ka czyński, Dwie na słońcach swych przeciwnych - boginie... Konflikt Izabeli Czartoryskiej z Elżbieta Lubomirska $w$ ujęciu literackim po 1945 roku. W zb.: Stynne kobiety $w$ Rzeczypospolitej XVIII wieku. Red. A. Roć k o, M. Gó r s ka. Warszawa 2017, s. 425-440.

43 Zob. He in e, Teatr Narodowy 1765-1766. Raporty szpiega (cBN Polona). Heine thumaczy rozmaite zachowania widzów przepełnieniem stojącego parteru.

Zob. T. Kostki ewi c zow a, Przyjemność $w$ XVIII wieku, perspektywa leksykologii, semantyki, estetyki. W zb.: Przyjemność $w$ kulturze epoki rozumu. Red. T. Ko stki ew ic zowa. Warszawa 2011, s 293-311. - B. J u d k o w i a k, Przyjemność w teoriach dramatyczno-teatralnych i jej osiemnastowieczne rewizje. W zb.: jw., s. 229-241. - N or k ow s ka, op. cit., s. 158-169.

45 Zob. M. Ci eń s ki, Pejzaże oświeconych. Sposoby przedstawiania krajobrazu w literaturze polskiej $w$ latach 1770-1830. Wrocław 2000, s. 50-52. 
go odbioru przez otoczenie była też praca nad opanowaniem zasad tańca, a także ćwiczenia pod kierunkiem maestra Dovinié, „pierwszego z najsłynniejszych metrów do tańca, zostającego u dworu księżnej generałowej Czartoryskiej”46. Osiągniętą harmonię wyglądu i gestyki połączonej ze sposobem mówienia, objaśniania i wartościowania dostrzegali, również w czasach późniejszych, goście poznający w towarzystwie księżnej Świątynię Sybilli ${ }^{47}$. Jako odbiorcy i słuchacze byli oni wzruszeni połączeniem patriotycznych treści z ekspresją mowy i ciała: „wdzięku słów, wyrazu twarzy i oczów, zawsze stosownie do przedmiotu... jeżeli mówiła o ojczyźnie" 48 .

Debiut teatralno-towarzyski Czartoryskiej rozpoczą czas jej wpływu na literaturę, czas powstawania jej literackich wizerunków, czas dalszych okazjonalnych wierszy jej poświęconych, czas malowania jej portretu komplementującą poezją ${ }^{49}$. Wobec obfitości takich utworów zdołamy tylko fragmentarycznie dopełnić listę wskazanych tu już tomów i edycji interpretujących dzieła poetów składających w ten sposób hołd księżnej ${ }^{50}$, choć niewątpliwie istnieje potrzeba zebrania literatury przedmiotu, dokumentującej stan badań nad jej znaczeniem w dziele polskiego oświecenia ${ }^{51}$.

Jako spektator teatralny Czartoryska wkrótce znalazła się w tak rzadkiej roli „pierwszego widza”, szanowanego przez starożytnych, ważnego dla scentralizowania

Ma gi e r, op. cit., s. 136. Cyt. za: Za w a d z ki, op. cit., s. 644-645. O sławnym w Europie „baletniku” Dovinié, znanym też jako Dovini (właśc. Louis d’Auvigny), pisał ze Stuttgartu do A. Tyzenhauza jego nadworny kapelmistrz L. Sitański - zob. B. M a m o n t o w i c z- Ł oj e k, Tancerze króla Stanisława Augusta 1774-1798. Początki polskiego baletu. Warszawa 2005, s. 53. Zob. też A. Regli ń s k a - J e mi oł, Droga do teatralnej formy tańca $w$ XVIII wieku. W: Formy taneczne $w$ polskim teatrze jezuickim XVIII wieku. Poznań 2012.

47 Problem wyznaczania i realizowania wartości, trwanie przy nich w postawach postaci literackich i twórców omawia T. Kostkiewiczowa w referacie: Osiemnastowieczne projekty antropologiczne: od oświecenia ku długiemu trwaniu, wygłoszonym on-line podczas konferencji $Z$ warsztatów badaczy oświecenia (26 XI 2020).

48 F. Prek, Czasy i ludzie. Wrocław 1959, s. 184. Cyt. za: H. J u rk ow s ka, Pamięć sentymentalna. Praktyki pamięci $w$ kręgu Towarzystwa Warszawskiego Przyjaciót Nauk i w Puławach Izabeli Czartoryskiej. Warszawa 2016, s. 369.

49 Zob. Libera, op. cit., s. 219-220, 266. - T. Ko st ki ew i czow a, Kobiety w liryce Kniaźnina. $\mathrm{W}$ zb.: Kobieta epok dawnych $w$ literaturze, kulturze $i$ spoteczeństwie. Red. I. M a ci ej ew s ka, K. St a si e w i c z. Olsztyn 2008, s. 75-88. - M. Pat r o, Okolicznościowy bukiet poetycki dla mistrzyni wdzięków i cnoty: „Na urodziny księżny Izabeli Czartoryskiej”. W zb.: Czytanie Kniaźnina. Red. B. Mazurkowa, T. Chachulski. Warszawa 2010.

50 Zob. E. Rabowicz, Stanisław Trembecki w świetle nowych źródeł. Wrocław 1965. - J. Platt, Sielanki i poezje sielskie Adama Naruszewicza. Wrocław 1967. - T. K o s t k i e w i c z o w a, Kniaźnin jako poeta liryczny. Wrocław 1971. - M. Nesteruk, Z. Rejman, wstęp i komentarze w: J. P. W o r o n i c z, Pisma wybrane. Warszawa 1993. - A. Al e k s a n d r o w i c z: Izabela z Flemmingów Czartoryska (1746-1835); Prawdziwie rycerskie igrzyska. W zb.: Rok $1809 \mathrm{w}$ literaturze i sztuce. Red. B. Czwór nó g-J a d czak, M. Ch a chaj. Lublin 2011, s. 137-150. - Cieński, op. cit., passim. Zob. też edycje - poprzedzone wstępami - w serii „Biblioteka Pisarzy Polskiego Oświecenia” oraz interpretacje w tomach serii „Czytanie Poetów Polskiego Oświecenia”.

51 Potrzebę badania twórczości literackiej Czartoryskiej dostrzegają G. Borkowska, M. Czermińska i U. Phillips, autorki monografii Pisarki polskie od średniowiecza do wspótczesności. Przewodnik (Przekł. tekstów U. Phillips: M. M o s a k ow ski. Gdańsk 2000, s. 37-38, 183). Zob. też J. S ow iń s ki, O uczonych Polkach. Warszawa-Krzemieniec 1821, s. 162-163. Cyt. za: J. Kow a 1, Literackie oblicze „Dziennika Wileńskiego” (1805-1806 i 1815-1830). Rzeszów 2017, s. 156-157. 
antycznej widowni. Sytuacja odbioru ułożyła się wszakże inaczej. W marcu 1767, gdy kończyła się antrepryza Stanisława Augusta, księżna po raz ostatni zasiadła w Operalni. Była jedynym widzem. Najpewniej zajęła miejsce w prosceniowej loży ambasadora Nikołaja Repnina, „pierwszej od sceny, po stronie królewskiej”, którą cechowała agresywna kolorystyka i boczne usytuowanie ${ }^{52}$. Boczna perspektywa loży powodowała pewną deformację obrazu scenicznego i zniekształcenie odbioru gry aktorskiej, co wynikało z obowiązujących reguł ustawienia artysty na scenie. Repnin, świadom tych mankamentów utrudniajacych oglądanie spektaklu, podjął decyzję o przebudowie loży, co zapisał w swej szyfrowanej depeszy rezydent saski radca Ludwig von Gablenz ${ }^{53}$, oceniając to głównie jako część planu przejęcia antrepryzy przez ambasadora ${ }^{54}$. Ta wyjątkowa sytuacja, obok spostrzeżeń dotyczących skutków braku publiczności i jej ożywionych reakcji, stanie się elementem refleksji Czartoryskiej, zawsze nastawionej na sytuację odbioru ${ }^{55}$. Spektakl, który tu przypominamy, miał też inne konteksty. W tymże marcu 1767, w środę popielcową, występ francuskiej trupy Josse Rousselois został opłacony przez Repnina, zapraszającego na przedstawienie tylko księżną i pracowników ambasady. Szpieg saski Heine szybko doniósł o politycznych intencjach Repnina i o złych opiniach na temat tej sytuacji, notował ów fakt także angielski dyplomata James Harris ${ }^{56}$. Dla Czartoryskiej, ceniącej klasycystyczną paryską i „warszawska” Comédie Française, był to spektakl z wysokiego repertuaru, szanowany przez teatry europejskie, kształtujący gusty oświeconych elit ${ }^{57}$.

Już wkrótce, w maju 1768, Czartoryscy rozpoczęli swą kolejną, blisko roczną, podróż do Francji i Anglii, będącą czasem i terenem doświadczeń kulturowych, kontynuowanych w wojażach lat późniejszych ${ }^{58}$. Duże uznanie Izabeli Czartoryskiej dla francuskiego repertuaru zadecyduje o spędzaniu wieczorów wiosną owego roku, a następnie jesienią 1773 w Paryżu na przedstawieniach Comédie Française, która przeniosła swą siedzibę do Pałacu Tuileries, zachowując tradycyjnie narodowy klasycystyczny repertuar. Paryskie doświadczenia teatralne księżnej są udokumentowane imiennym biletem do małej loży Comédie Française na dzień 16 X 1773. W rachunkach podróżnych księżnej zachowało się nadto rękopiśmienne pokwito-

H e in e, Teatr Narodowy 1765-1766. Raporty szpiega (cBN Polona), s. 9.

Zob. Kli m ow i c z, Poczatki teatru stanisławowskiego, il. 11, po s. 144.

Zob. Gazety pisane z Warszawy r. 1767, sygn. 583 I, k. 32. W: J a ckl, Teatr i życie teatralne $w$ gazetach i gazetkach pisanych (1763-1794), s. 485-486.

Zob. wypowiedzi I. Czartoryskiej w: B. Zaleski, Żywot księcia Adama Jerzego Czartoryskiego. Cyt. za: A. Wh ela n, Izabela Czartoryska-fety, jarmarki i amour propre. W zb.: Stynne kobiety w Rzeczypospolitej XVIII wieku, s. 261-274.

Zob. streszczenie raportów szpiegowskich Heinego w: J a ck1, Teatr i życie teatralne $w$ gazetach igazetkach pisanych (1763-1794), s. 485, przypis 2. Zob. też J. H a r r i s, Dziennik pobytu w Polsce (1767). W zb.: Polska stanisławowska w oczach cudzoziemców. Oprac., wstęp W. Zaw a d zki. T. 1. Warszawa 1963, s. 303.

Zob. Teorie dramatyczne oświecenia francuskiego. Przeł., oprac. E. Rzadkows ka. Wrocław 1958, s. 17. - Rataj c zakow a, Komedia oświeconych, s. 60-61.

Zob. Aleksandrowicz, Izabela z Flemmingów Czartoryska (1746-1835), s. 610-614. R. D a m p c - J a r o s z, Wpływ włoskich podróży na działalność Anny Amalii von Sachsen-Weimar-Eisenach i Izabeli Czartoryskiej. W zb.: Polski Grand Tour w XVIII i poczatkach XIX wieku. Red. A. Roćko. Warszawa 2014, s. 201-214. 


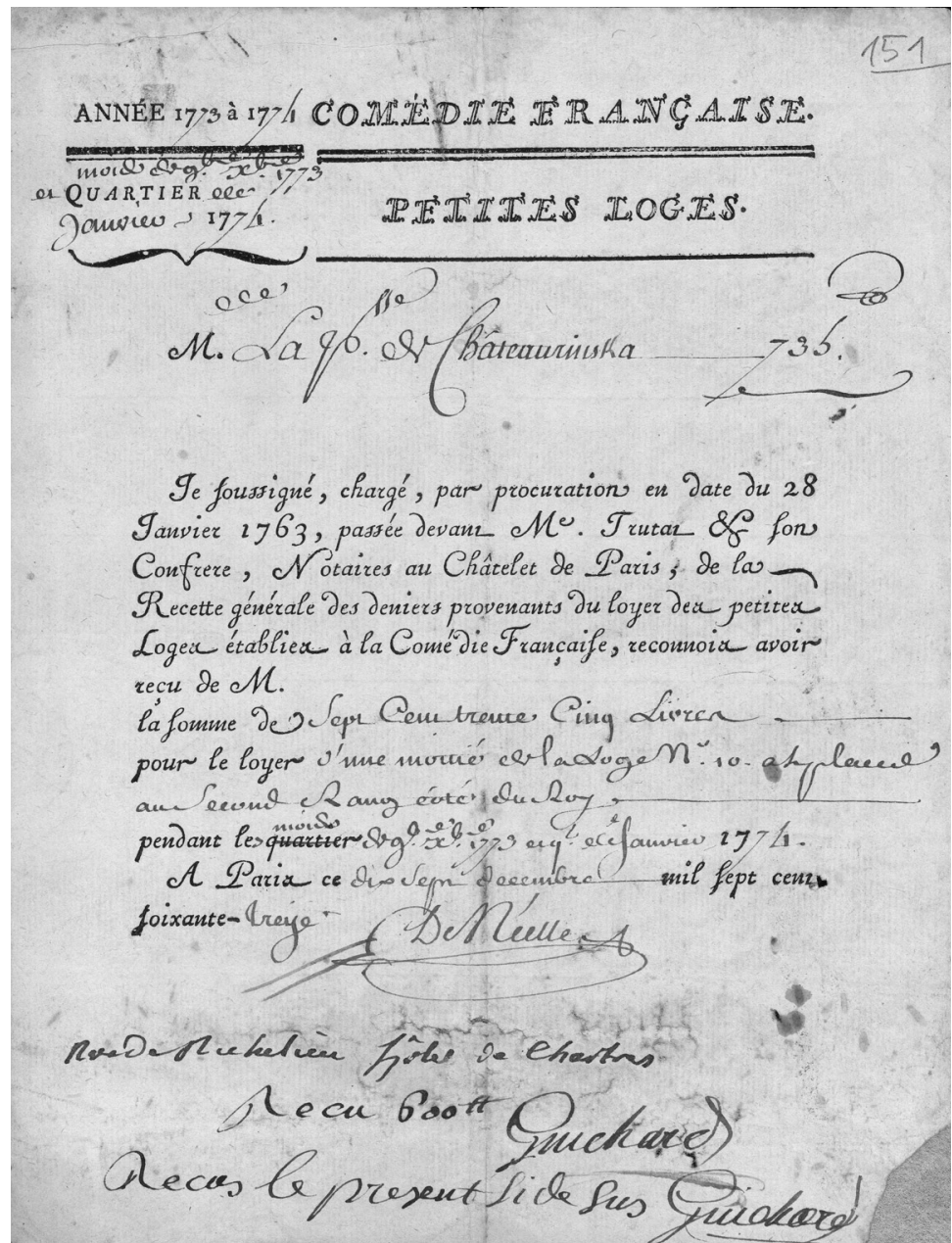

Izabela Czartoryska, Rachunki podróżne: rachunek za małą lożę w Comédie Française w Paryżu z 16 X 1773 (ze zbiorów Muzeum Narodowego w Krakowie, MNK 17 - rkps - 6077 - IV t. 4, k. 151) Foto Archiwum Fotograficzne MNK - Jarosław Cyganik

wanie do tegoż biletu za dostawienie czterech krzeseł, uzupełniających wyposażenie loży. Spektakl oglądano więc w grupie towarzyskiej ${ }^{59}$.

Bezpośredni odbiór i znajomość klasycystycznego repertuaru francuskiego dochodzi do głosu w późniejszych obszernych notatkach Czartoryskiej o dramatach i europejskich dramaturgach; wzbogaciło to także jej wiedzę warsztatową o aktorstwie scenicznym ${ }^{60}$.

Zagraniczne podróże umożliwiły też księżnej wybory repertuarowe. „Wiadomo-

Zob. Bibl. Czartoryskich, rkps 6077, t. 4.

Notatki w: Bibl. Czartoryskich, rkps 3035 III; rkps 6070 III. Autorka niniejszego artykułu dziękuje Panu Profesorowi Januszowi Pezdzie z Uniwersytetu Jagiellońskiego za udostępnienie Inwentarza rękopisów Biblioteki XX Czartoryskich $w$ Krakowie (Oprac J. N o w a k, J. P e z d a. 
ści Warszawskie" donosiły w 1768 r., iż w Brukseli stała się widzem indywidualnie ustalającym repertuar. Na osobista prośbę Czartoryskiej, oczekującej przyjazdu małżonka, aktorzy brukselscy przygotowali, cieszacą się już od roku popularnością w Paryżu, angielską dramę mieszczańską Edwarda Moore’a The Gamester, w wersji francuskiej: Beverley, ou le Joueur anglais. Korespondent „Wiadomości” rejestrował w „Suplemencie” książęca gratyfikację dla brukselskich aktorów ${ }^{61}$. Dodajmy, iż wystawiony w Warszawie blisko 10 lat później (lipiec 1777), promowany przez Czartoryska, Bewerlej, czyli Gracz angielski stał się jednym z największych sukcesów warszawskiego teatru; wznawiano go co parę lat ${ }^{62}$. Jak pisał w Dziejach teatru Wojciech Bogusławski, „po premierze cała Warszawa przez kilka tygodni tylko o tym rozmawiała"63. Wybór i wystawienie tego repertuaru wiązały się z inicjatywą obojga Czartoryskich - Franciszek Barss dedykował swój przekład dramy Moore’a „staranną i piękną prozą" księciu Adamowi ${ }^{64}$. W okresie przygotowań księżna Czartoryska wraz z marszałkową Lubomirską uczyły początkującą Agnieszkę Truskolaską, obsadzoną w roli pani Bewerlej, aktorstwa, wzorowanego na klasycystycznych przykładach gry Clairon (Claire-Josephine Légris de Latude) i Madeleine Arnould, najsławniejszych, zdaniem pamiętnikarki Anny Nakwaskiej, artystek paryskich. Styl gry Clairon był znany i akceptowany w Warszawie; wcześniej artystka, utraciwszy angaż w Paryżu, przesłała na ręce Stanisława Augusta (za pośrednictwem Repnina) wykaz swych ról, prosząc o zatrudnienie w Polsce ${ }^{65}$. Ze względów finansowych prośba nie została zaaprobowana. Zarazem pod wpływem publiczności mieszczańskiej stopniowo odchodzono od deklamacyjnego stylu gry; w czasie pracy księżnej z Truskolaską nad kolejną główną rolą (w tragedii Meropa Woltera, wystawionej w r. 1792) przyjmowano model "gry naturalnie natchnionej”, charakteryzującej styl Marie Dumesnil - następczyni Clairon ${ }^{66}$.

Spotkania z kultura europejską owocowały w postawie Czartoryskiej refleksją nad samodzielnym precyzowaniem „nowych sposobów życia i organizacji kultury”, a także poszerzały obszary jej wiedzy ${ }^{67}$. W Londynie księżna przeżyje fascynację

Kraków 2020) i za naukową pomoc w kwerendzie źródłowej w zbiorach Bibl. Czartoryskich w Krakowie.

61 „Wiadomości Warszawskie” 1768, nr 77, z 24 X, „Suplement”. Podajemy za: J a ck 1, Teatr i życie teatralne $w$ gazetach i gazetkach pisanych (1763-1794), s. 488-489.

62 Zob. J. K o t t, Główne problemy teatru w dobie oświecenia. W zb.: Teatr Narodowy w dobie oświecenia, s. 15.

63 Bogusławski, op. cit., cz. 1, s. 13.

64 F. B ar s s, Bewerlej, czyli Gracz angielski. Tragedia w pięciu aktach. W zb.: Drama mieszczańska. Oprac. J. P a wł ow i c z o w a. Warszawa 1955, s. 35-37, 127-228. (Jest to przekład dramy Moore’a $z$ francuskiej przeróbki B. J. Saurina.)

65 Wykaz ról aktorki Clairon (tu dwa wpisy ręką króla, koniec 1766 r.). Arch. Jabłońskie, rkps A/178b, chap. VI, nr 12. W: K. Wi e r z bi c ka, Źródła do historii teatru warszawskiego od roku 1762 do roku 1833. Cz. 1: Czasy stanisławowskie. Wrocław 1951, s. 98.

66 Zob. M. Dębow ski: wstęp w: E. Murray, O aktorach i grze teatralnej / Des acteurs et du jeu theatral. Przeł., oprac. M. D ę b ow s ki. Kraków 1991, s. 10-20; Trzy szkice o aktorstwie tragicznym $w$ dobie oświecenia i klasycyzmu. Kraków 1996, s. 70-72; Francuskie konteksty teatru polskiego. Kraków 2001, s. 145-146.

67 Zob. A. Ale k s a n d r ow i c z: Izabela z Flemmingów Czartoryska (1746-1835), s. 610-611; Izabela Czartoryska. Polskość i europejskość. Lublin 1998, s. 165-298. 
twórczością dramatyczną i koncepcją wielkiego teatru Williama Szekspira oraz osjanicznym kultem postaw rycerskich ${ }^{68}$.

Jej podziw dla Szekspira wyzwolił potrzebę lektury dzieł wielkiego dramaturga i upamiętnienia, jako wizualnego przekazu, zawartych w nich treści uczuciowych o zakodowanej wartości emocjonalnej i znaczeniu symbolicznym ${ }^{69}$. Dokumentuje więc księżna sferę swych przeżyć esejem stanowiącym własne odczytanie tragedii Romeo i Julia, gromadzeniem osobistych przedmiotów-pamiątek genialnego autora, subskrypcja jego dzieł i poznawaniem związanych z nim miejsc, takich jak nagrobek dramaturga, galeria poświęconych mu obrazów czy dom aktora szekspirowskiego Davida Garricka ${ }^{70}$. Portret Szekspira i stojące obok krzesło, przywiezione do kraju, eksponowane w Puławach, buduja jako całość niewerbalny komunikat wskazujący na czczonego artystę teatru. Pamiątka ma wielką siłę przekazywania treści ważnych dla Czartoryskiej, która w swych notatkach przytaczała myśli autora Hamleta, fragmenty jego dramatów, własne rozważania nad jego oceną postaw ${ }^{71}$. Tak powstawał zróżnicowany przekaz, łączący literaturę dramatyczną, miejsca pamięci oraz przedmioty kultowe - pamiątki, portrety, wydania utworów i obszerne osobiste komentarze interpretujące arcydzieła ${ }^{72}$. Zarazem można dodać, że Czartoryska zapisywała uwagi o innych autorach, takich jak Jean de La Fontaine, Jean-François Marmontel, Molier, Jean-Jacques Rousseau, a także o artystach malarzach; tu wyróżnia się notatka o słynnym obrazie Leonarda da Vinci Portrait ou Tableau fait par Leonardo, przywiezionym właśnie $z$ Włoch przez syna księżnej Adama Jerzego ${ }^{73}$.

Po zagranicznych wojażach, jak i w przerwach między nimi, księżna kontynuuje swój aktorski udział w przedstawieniach stołecznych teatrów prywatnych. W życiu kulturalnym socjety występuje co tydzień wraz z grupą arystokratycznych aktorów-amatorów we francuskim repertuarze prywatnego teatru Stanisława Augusta i w théåtre de société Magdaleny z Lubomirskich Sapieżyny. Rozwój prywatnych teatrów należących do arystokracji warszawskiej możemy datować na schyłek lat siedemdziesiąych. Na datowanie pozwala nam m.in. zachowana akwarela Norblina z 1778 r., przedstawiająca Czartoryską w roli ogrodniczki Marianne w operze komicznej Antonia M. Sacchiniego La Colonie, z librettem Pietra Metastasia; włoska wersja opery znana jest pod tytułem L’isola d'amore. Utwór należał do najnowszego, cenionego w Europie repertuaru; skomponowany zaledwie cztery lata

Zob. Ale k s a n d r ow i c z, Izabela Czartoryska, s. 165-299. - Z. G ołę bi ow s ka, W kręgu Czartoryskich. Wptywy angielskie $w$ Puławach na przełomie XVIII i XIX wieku. Lublin 2000. - R. B u tt erwick, Stanisław August a kultura angielska. Przeł. M. Ugni ew ski. Warszawa 2000, s. $165-213$.

69 Zob. T. Kostkiewiczowa, Sentymentalizm. Hasło w: Stownik literatury polskiego oświecenia. Red. T. Kostkiewi czowa. Wyd. 2, poszerz. i popr. Wrocław 1996. - Oświeceniowe zapisywanie pamięci. Red. M. Cha chaj, A. Timofiejew. Lublin 2019. Zob. też A. Cieński, Pamiętnikarstwo polskie XVIII wieku. Wrocław 1981, s. 10-12. Zob. Ale k s a nd row i c z, Izabela Czartoryska, s. 261-278.

71 Zob. I. C za rt o ry s ka, Extraits et Mélanges de différents genres pour La Maison Gothique à Pulavy, 1809. Bibl. Czartoryskich, rkps 6070 III, t. 3 (1782-1820), s. 22, 35-59 n.

72 Zob. A. Ale k s a nd r ow i c z, Kult Szekspira i Osjana na dworach Czartoryskich. W: Izabela Czartoryska, s. 261-298.

73 Bibl. Czartoryskich, rkps 3035 III, s. 90. 


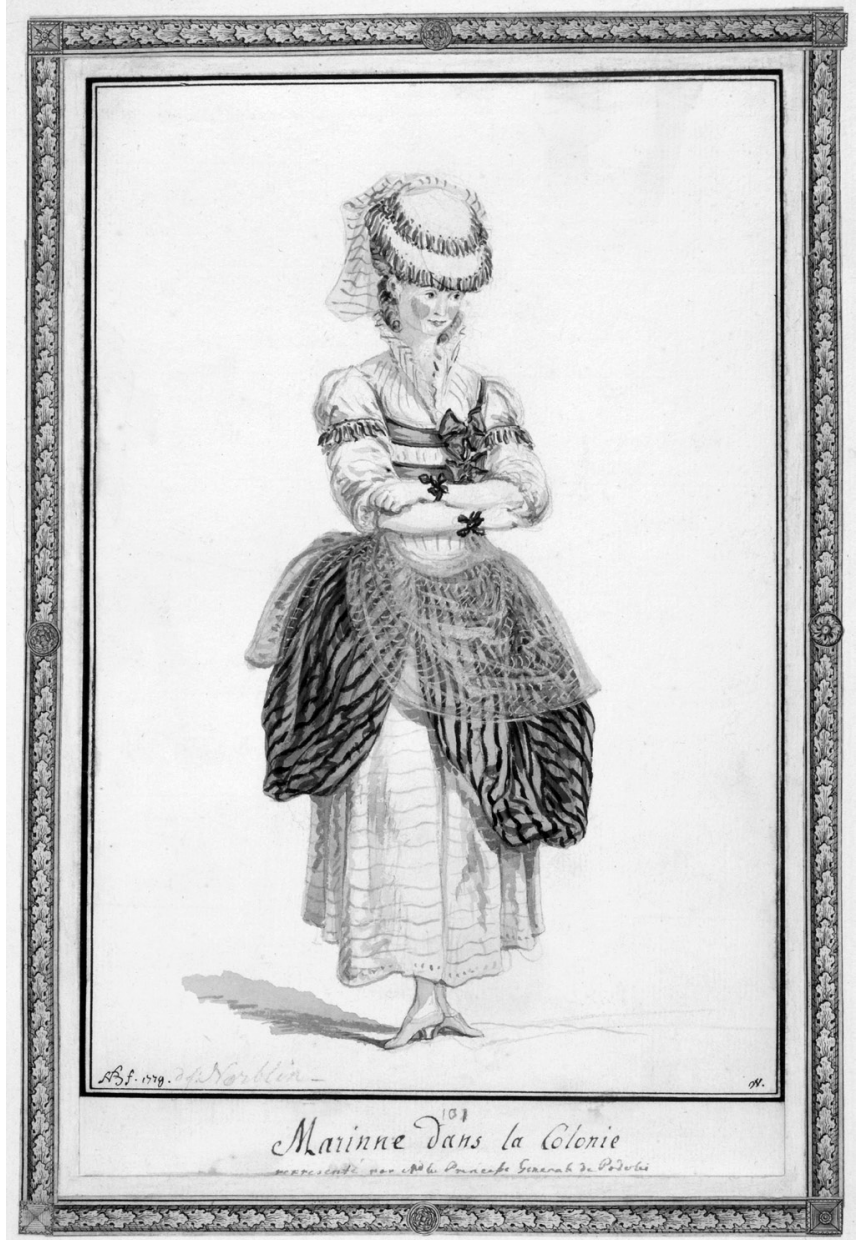

J. P. Norblin, Izabela Czartoryska w roli ogrodniczki Marianne (1779/80) (akwarela ze zbiorów dawnych Gabinetu Rycin BUW, nr inw. zb.d. 7867)

wcześniej w Londynie, był wystawiany kolejno w Lizbonie, Paryżu, Mannheim, Brukseli, Wiedniu, Esterhaz, Kopenhadze i innych miastach ${ }^{74}$. Warszawski spektakl La Colonie w pałacu księżnej Sapieżyny wspominał Adam Jerzy Czartoryski: partie śpiewane wykonywali „księżna Radziwiłłowa $z$ domu Przeździecka, $z$ bardzo pięknym głosem, moja matka [Izabela Czartoryska], pan Wojna, późniejszy ambasador w Rzymie, i generał artylerii Brühl" ${ }^{75}$. Zarówno generała Alojzego Brühla, jak

Zob. I. M a m c z a r z, Les Intermédes comiques italiens au XVIII siècle, en France et en Italie. Paris 1972, s. 555-572.

75 A. J. Czartoryski, Pamiętnik. T. 1. Kraków 1904, s. 17-18. Cyt. za: Zawadzki, op. cit., s. 647-648. Zob. też I. Ka duls ka, Helena Radziwiłłowa - korespondentka z Arkadii. W zb.: Kobieta epok dawnych $w$ literaturze, kulturze i społeczeństwie. 
i szambelana Franciszka Wojnę ceniono jako znakomitych muzyków amatorów ${ }^{76}$. Śpiew Czartoryskiej zachwycał brzmieniem czystym i silnym, połączonym z delikatną barwą. Jeden ze słuchających notował, że głos jej uznawano za dorównujący „pierwszym w Europie kastratom”. Zaraz też dodawał niechętnie: „Ale wiele do tego pomogło, że to księżna i Czartoryska, i Adamowa" 77 .

Prezentowana akwarela Norblina mistrzowsko utrwala zarówno aktorski wdzięk księżnej w roli Marianny, jak i charakteryzację oraz odpowiedni do tej roli kostium, który przypomina zwyczajny, lecz powabny ubiór: całość zdobiona wstążkami, dopasowany staniczek, udrapowana baskinka w talii, tiulowy fartuszek, spódniczka na rogówce o długości powyżej kostki, odsłaniająca „nieporównaną nóżkę"78, nieduży kapelusik na podwyższonej fryzurze, pantofelki z przesunietym ku przodowi obcasem, co optycznie zmniejsza stopę, oraz adekwatny do roli makijaż sceniczny (róż na policzkach w kształcie serduszek). Jest to portret Czartoryskiej jako wykonawczyni pięknych ról, zarazem popularyzatorki sztuki teatralnej w kręgach warszawskiej elity. Pamięć o tej roli była wśród odbiorców entuzjastycznie długotrwała; w zbiorze puławskiej korespondencji $z$ lat 1784-1800 zachował się ozdobiony purpurową pieczęcią francuski bilecik kwiatowy adresowany do Puław: „À Mademoiselle Marianne Czartoryska, Uwielbiana Ogrodniczka"79.

Gazetki pisane z Warszawy z 1782 r. donoszą, iż „w zamku [królewskim - I. K.] co tydzień teraz grana bywa komedia”, i podkreślają udział „księżnej Adamowej”, zachwycającej urodą i piękna grą ${ }^{80}$. Spośród licznych spektakli towarzyskich, w których księżna wystąiła, wymienić możemy tylko, notowane w źródłach przykładowo, ponowne wystawienie wspomnianej opery La Colonie w lutym 1783, $\mathrm{w}$ wieczór inaugurujący prywatny teatr Stanisława Augusta na zamku ${ }^{81}$. Jednak udział Izabeli w tym spektaklu wydaje się wątpliwy, choćby $z$ uwagi na ówczesne relacje Czartoryskich $\mathrm{z}$ królem ${ }^{82}$.

Więź z szerszą publicznością zapewniał teatr Pałacu pod Blachą. Budził on wielkie zainteresowanie widzów, którzy już od 1798 r. „nieraz i dzień cały trawili na zdobywaniu miejsca". Odstępne za krzesło kosztowało kilka dukatów ${ }^{83}$. Ta sytuacja jest szczególnym przykładem oświeceniowej „komercjalizacji widowisk, odciskającej piętno na repertuarze teatralnym i przynoszącej zmianę zasad społecznego funkcjonowania teatru" 84 . Tu właśnie aktorami byli arystokraci, wśród nich Czartoryska z córką Marią, także Konstancja Tyszkiewiczowa „Z piękną córką

Zob. A. Żu raw s ka - W it k ow s ka, Muzyka na dworze i w teatrze Stanisława Augusta. Warszawa 1995, s. 164.

Ibidem.

S. Tr e m b e c ki, Powazki. Idylla, w. 204. W: M. Nale pa, Koncept ogrodowy i poetycki. „Powazki. Idylla". W zb.: Czytanie Trembeckiego. Red. J. Snope k, W. Kali s zew s ki, B. Mazu rk owa. T. 1. Warszawa 2016, s. 153-191.

Korespondencja rodzinna. Listy do Marii z Czartoryskich Wirtemberskiej od matki Izabeli.

Gazety pisane $z$ Warszawy 1782, sygn., 2037, s. 312. W: J a c k l, Teatr $i$ życie teatralne w gazetach i gazetkach pisanych (1763-1794), s. 538.

Zob. E. Szw a n k ow s ki, Teatry Warszawy w latach 1765-1918. Do druku przygot. M. W o si e k. Posł. M. M. Drozdowski. Warszawa 1979, s. 31.

Zob. Żurawska-Witkowska, op. cit., s. 164 i 172, przypis 127.

Z. Raszews ki, Bogusławski. T. 2. Warszawa 1972, s. 92.

Zob. Parkitny, op. cit., s. 63. 
Anetką". W ich repertuarze podziwiano szczególnie wystawienie Cyrulika sewilskiego w języku francuskim, najpewniej z udziałem księżnej ${ }^{85}$. Ważny był także rodzinno-towarzyski pobyt w Siedlcach u hetmanowej Aleksandry z Czartoryskich i występ w 1786 r. w teatrze przy pałacu Ogińskich. Tu księżna mogła z satysfakcją wygłosić ze sceny moralne przesłanie, grając w Cyganach Kniaźnina ${ }^{86}$. Egzotyczny temat życia taboru cygańskiego zaproponowała poecie Czartoryska, podpowiadająca także nowatorska, folklorystyczną inscenizację ${ }^{87}$. Scenicznym znakiem autentyczności roli starej Cyganki - wróżki Jawnuty - stał się kostium Izabeli: stylizowany czerwony szal na ramionach i nakrycie głowy. W cygańskim stroju sportretował ją Kazimierz Wojniakowski, wykształcony w Malarni Królewskiej przez Marcella Bacciarellego. Portrety Czartoryskiej-aktorki stanowią cenną i rzadką dokumentację teatralną oraz kulturowa.

Około 1773 r. Czartoryska rozpoczęła realizację pomysłu gry-zabawy-maskarady przestrzennej, związanej z siedzibą w Powązkach ${ }^{88}$. Powązki, podwarszawskie mokradła, które dzięki księżnej - oraz współautorowi projektu, Norblinowi - zyskały charakter wyrafinowanej magnackiej siedziby, ukostiumowanej w skromne szaty architektury rustykalnej, to przykład „odmiennej strategii nadawania” 89 . Kompozycja przestrzeni, konstrukcja chatek, które grają swe role przypisane im przez szyldy, to sygnał nowego myślenia księżnej - myślenia kategoriami teatralizacji, upowszechniającej określony $z$ góry sens tych emblematów ${ }^{90}$. Znaczenie pańskiej siedziby, stylizowanej na pełna prostoty, ale i wyrafinowania, komunikowane jest przez struktury niewerbalne. Do zapraszanych gości przemawiaja przestrzenie ogrodu, ukształtowanie krajobrazu, we wnętrzu zaś zaskakuje kontrast między oczekiwaniem a zastanym obrazem ${ }^{91}$. Nastrojowości wiejskich wieczorów

Zob. ibidem. Zob. też S. D u ch iń s ka, Wspomnienia z życia Marii z ksiażąt Czartoryskich Wirtemberskiej. Warszawa 1886, s. 163. - J. F alkow s ki, Księstwo Warszawskie. Obrazy z życia kilku ostatnich pokoleń w Polsce. T. 1. Warszawa 1906, s. 58-61. - Dramat obcy w Polsce 1765-1965. Premiery, druki, egzemplarze. Informator. [T. 1:] A-K. Praca zesp. pod kier. J. M i c hali ka. Red. tomu: S. Hałabu da. Kraków 2001, s. 64-65.

86 Zob. Wierzbicka-Michalska, op. cit., s. 269-279. - U. Głowacka-Maksymiuk, Aleksandra z ksiażąt Czartoryskich Ogińska. Siedlce 2003. - A. C zy ż, Podlaska ojczyzna Tomasza Kajetana Węgierskiego. W zb.: Od liryki do retoryki. W kręgu słowa, literatury i kultury. Red. I. Kadulska, R. Grześk owiak. Gdańsk 2004, s. 221-237. - A. Zi o n t e k, Aleksandra Ogińskażycie i legenda literacka. W zb.: Aleksandra Ogińska i Siedlce $w$ trzech pamiętnikach z XIX wieku. Oprac., wstęp R. D mowski, A. Zi on tek. Siedlce 2007, s. 9-44. - K. St a si e wi ic z, Kobiece przyjemności $w$ XVIII wieku. W zb.: Przyjemność $w$ kulturze epoki rozumu. Zob. M. Kli m ow i c z, Oświecenie. Warszawa 1972, s. 286-287.

88 Zob. Aleks a n d row i c z, Izabela z Flemmingów Czartoryska (1746-1835), s. 611-612. - Ry b a, op. cit.

89 M. C i eń s ki, Przyjemności parkowe i ogrodowe $w$ życiu i literaturze polskich oświeconych. W zb.: Przyjemność $w$ kulturze epoki rozumu, s. 56-57. Zob. też D. Kow a lew s k a, Sentymentalne chaty i rokokowe chatki. W zb.: Rzeczpospolita domów. [T.] 2: Chaty. Red. K. Kr a w i e c-Zł o t k o wska. Słupsk 2010, s. 142-152. - J. Sawi cka-Jurek, Chata wiejska tematem architektury i imprez maskaradowo-teatralnych na dworach magnackich $w$ XVIII wieku. W zb.: jw., s. 175-184.

90 Zob. Braun, op. cit., s. 47. - J. Ci e c howi c z, Myślenie teatrem. Gdańsk 2000.

91 Zob. S. Trembe cki: Powazki I; Powązi. Epigramma. Zob. też A. N a siłow s k a, Poezja opisowa Stanisława Trembeckiego. Wrocław 1990, s. 71-114. - Kow alew s k a, op. cit., s. 142-153. Sawicka-Jurek, op. cit., s. 175-183. - Nale pa, op. cit., s. 153-191. 
towarzyszyły koncerty ukrytej orkiestry oraz iluminacje, urzekające sztuką wielobarwnych świateł, zapraszających do świata innej akcji, tysiącami lamp, odbijających się w nurcie wody. Zanotował to podróżujący po Polsce William Coxe, angielski historyk i wydawca ${ }^{92}$. Swój zachwyt relacjonował w kategoriach percepcji teatralnej: oglądania i słuchania ${ }^{93}$.

W powazkowskim projekcie niewątpliwie zwraca uwagę przygotowana przez Czartoryską, wspólnie z grupa wykonawców, jedna z pierwszych prób żywych obrazów. Przedstawione w scenerii ogrodu Podpisanie pokoju chocimskiego było przykładem teatralizacji historycznej, wzorowanej na obrazie Bacciaerllego Pokój chocimski, która wprowadzała postaci quasi-rzeczywiste z tamtego czasu. Uczestnicy grupy ustawionej $\mathrm{w}$ obrazie byli bowiem autentycznymi reprezentantami rodów zwycięzców spod Chocimia, którzy wystapili $z$ odziedziczonymi sztandarami i nałożyli historyczne zbroje ${ }^{94}$. To powązkowskie doświadczenie rozwinie się $\mathrm{w}$ kultywowanie ojczystych dziejów w szeregu inicjatyw kulturalnych Puław i Sieniawy.

Bywająca w Powązkach liczna grupa towarzyska miłośniczek i miłośników teatru przygotowywała występy mające sprawiać przyjemność właścicielce siedziby. Połączona wewnętrznymi więziami i wzajemnym oddziaływaniem, grupa ta rozwijała niekonwencjonalne formy, nadając im niekiedy sens podwójnej gry ${ }^{95}$. Adam Jerzy Czartoryski wspomina m.in. przedstawienie Piętnastoletni kochanek w powązkowskiej owczarni, reżyserowane przez Marię Teresę z Poniatowskich Tyszkiewiczową efektowna i ekscentryczną siostrę księcia Józefa Poniatowskiego. Przyjęła ona w spektaklu rolę kochanka i przebrana po męsku wjechała do owczarni konno, realizując metateatralną koncepcje bycia kimś innym w „teatrze”, który był tu przestrzenią innych przeznaczeń. Swój talent inscenizacyjny wykorzystała adaptując komedię L'Amant anonyme pani de Genlis ${ }^{96}$.

Warto też zwrócić uwagę na inną formę teatralną - na świąteczne jasełka wystawiane w przenośnym teatrze lalek. Zachowane dwa obrazy Norblina (powązkowski olej na desce dębowej i późniejszy puławski gwasz) dokumentują ten typ tradycyjnych przedstawień łączących $w$ jedną postać wykonawcę-animatora $z$ teatralną lalka. Powązkowski spektakl lalkowy posiadał zasadnicze cechy teatru: widownię z zasiadająca publicznością oraz scenę wypełniona ,aktorami” i wyposażoną w dekorację - blejtram w funkcji tylnego prospektu $\mathrm{z}$ rysunkiem budynków w stylu orientalnym. Perspektywiczną "głębię" tworzyły proporcjonalnie malejące figurki umieszczone po bokach. Były to widowiska dla dziecięcego odbiorcy, jednak z udziałem również publiczności dorosłej - rodziców. Datowany na przełom 1779 i 1780 r. obraz olejny przedstawia księżną Izabelę siedzącą wraz z księżniczką Marią tuż przed kurtyną, która osłania animatorów grających lalkami. Izabela odwraca się do stojącej za nią księżniczki Teresy i coś objaśnia, gestykulując. Wyprostowana Teresa

W. Coxe, Podróż po Polsce 1778. W zb.: Polska stanisławowska w oczach cudzoziemców, t. 1, s. 663-664.

93 Zob. H. Dziechcińska, Ogladanie i słuchanie $w$ kulturze dawnej Polski. Warszawa 1987, s. 9-89. - Ka d u ls k a, Magia ogni kunsztownych $w$ spektaklach plenerowych XVIII wieku, s. 99100.

Zob. Whelan, op. cit., s. 273.

Zob. Dmitruk, op. cit., s. 10-15.

Zob. A. J. Czartoryski, op. cit., s. 17-18. 
w błękitnym kapelusiku, patrząca w górę, jest usytuowana idealnie - odpowiednio do wysokości sceny lalkowej ${ }^{97}$ (widzowie siedzący mieli utrudniony odbiór; Norblin utrwalił kłopotliwość tej relacji przestrzennej). Powstały kilka lat później puławski gwasz dokumentuje korektę i refleksję księżnej nad sposobem rozmieszczenia publiczności i rozwiązaniem proksemiki teatralnej. Proporcja wysokości sceny względem odległości usytuowania oglądających jest tu odpowiednia.

O włączaniu medium teatralnego w kształtowanie osobowości dzieci pisała Maria Wirtemberska i pamiętał to z czasów dzieciństwa Władysław - wnuk Izabeli. Jego wspomnienia obejmują także aktywność księżnej - animatorki wielu form życia teatralnego w siedzibie rodowej w Puławach ${ }^{98}$.

Jak już powiedziano, po powrocie z Anglii w 1791 r., podczas trwających jeszcze obrad Sejmu Wielkiego, księżna manifestacyjnie wyrażała swą postawę polityczną. Prowadziła intensywną agitację wśród dam, organizując ich zbiorowy protest na galerii sejmowej w dni, gdy miano omawiać politykę rosyjską ${ }^{99}$. O wyrazistości tych zaplanowanych manifestacji pisze Niemcewicz. Przypomina zwłaszcza gesty, ruchy, okrzyki księżnej, klaszczącej w dłonie, wymachującej energicznie szalem na znak protestu ${ }^{100}$. Ten rodzaj widowiskowej manifestacji miał charakter sytuacyjny i zarazem materialny. Wymagał obecności odbiorców-obserwatorów: posłów patriotów, którym księżna przekazywała stanowisko grupy kobiet i swoje, wręczając niekiedy kwiaty ${ }^{101}$. Ta forma teatralizacji zaprezentowana w miejscu publicznym nadawała protestowi wymiar polityczny ${ }^{102}$.

Do kategorii widowisk kulturowych inscenizowanych przez księżną w okresie obrad Sejmu należała teatralizacja, którą można by nazwać: „powrót do sarmackich ubiorów i wyglądów”. W przestrzeni prywatnej, podczas śniadania, zaproszeni goście obserwowali scenę w wykonaniu Czartoryskiej. Jako osoba o wysokim znaczeniu, przyjęła ona funkcję medium rozstrzygającego racje sporu między frakiem a kontuszem - po sarmacku przycięła ufryzowane francuskie loki księcia Kazimierza Nestora Sapiehy ${ }^{103}$. Akcja zmiany wyglądu, wzmocniona efektami fonicznymi,

97 Obraz olejny Norblina przedstawiający spektakl teatru lalek został namalowany na prośbę króla w 1779/80 roku. Oryginał znajduje się w Muzeum Narodowym. Możliwe, że jest to ostatni wizerunek księżniczki Teresy - przed tragicznym wypadkiem. Reprodukcje obu obrazów w: H. J u r k o ws k i, Dzieje teatru lalek. Od antyku do romantyzmu. Warszawa 1970, il. 32, 33, po s. 72. Zob. też P. Ka c zy ń s ki, Rodzina w literaturze stanisławowskiej. Motywy-konwencje-poglady. Wrocław 2009, s. 198-199. - A. Szm u c, Czartoryscy $w$ poezji, prozie wspomnieniowej i korespondencji Franciszka Karpińskiego. W zb.: Wirydarz staropolski i oświeceniowy. Red. R. Ma g ry ś, J. Ko wal, G. Trościńs ki. M. N a le pa. Rzeszów 2020, s. 450-451. Podkarpacie literackie. T. 1.

Zob. Aleksandrowicz, mowic i frak. O symbolice stroju $w$ XVIII-wiecznej literaturze polskiej. Warszawa 2015, s. 60-70. Zob. też Zagadki Sejmu Czteroletniego. Teksty zebrał i ustalił E. Rabowicz. Koment. B. Krakow ski, E. Rabowicz. Do druku przygot. J. Kow e cki. Warszawa 1996, s. 163-165. 
służyła przywróceniu narodowego wizerunku, a poezja polityczna jako medium słowne dopisała komentarze literackie ${ }^{104}$. Przedstawiona tu teatralizacja „W życiu społecznym ma zadanie zakomunikowania danej wspólnocie [...] w sposób dobitny i wyrazisty jakiegoś zdarzenia, jego szczególnego znaczenia, przemian, [...] wywarcie doraźnego skutku na uczestnikach, widzach"105.

Miejscem manifestacji postaw narodowych i utrwalania tożsamości kulturowej stała się od r. 1783 siedziba Czartoryskich w Puławach ${ }^{106}$. Teatr w posiadłości rodu cechuje dynamiczny rytm przedstawień, przygotowywanych z profesjonalną starannością i wiedzą ${ }^{107}$ - w nowoczesnej wspólnocie twórców, wykonawców i odbiorców. Tę aktywną wspólnotę konstytuują księżna - inspiratorka i reżyser, autorzy-literaci: Adam Kazimierz Czartoryski, Franciszek Dionizy Kniaźnin, Maria Wirtemberska, jak też grono wykonawców, składające się z powiązanych rodzinnie domowników, a także przyjaciół, przy obecności prestiżowych gości, niekiedy zaś okolicznych mieszkańców, i w połączeniu z możliwościami scenograficznymi oraz sytuacją przestrzenną dworu. Rozwijają się tu również pozasłowne formy teatru: widowiska-maskarady plenerowe ${ }^{108}$, uporządkowane teatralizowane pochody i żywe obrazy. Zarazem w atmosferze teatralnej Puław, pod patronatem księcia Czartoryskiego, powstał w latach 1808-1811 pionierski podręcznik estetyki gry aktorskiej, przeznaczony do kształcenia adeptów Szkoły Teatralnej Wojciecha Bogusławskiego ${ }^{109}$.

Żywe obrazy mieszczą się w formule teatru, aczkolwiek chodzi tu wyłącznie o ikoniczne przekazywanie treści, oparte na „rozumiejącym” oglądaniu grup osób odtwarzających znany obraz. Odbiór żywego obrazu wymaga rozpoznania historycznego oryginału i znaczenia dzieła sztuki malarskiej ${ }^{110}$. Wykonawcy nie maja statusu artystów; występ polega na mimetycznym ustawieniu, ukostiumowaniu, wyposażeniu w rekwizyty - nierzadko przedmioty autentyczne, swiadectwa historii. Funkcją żywych obrazów jest przypominanie, utrwalanie oraz upowszechnianie wiedzy i postaw ${ }^{111}$. Odbiór ma często charakter patriotycznej refleksji, odpowiednio do treści zakodowanych w oryginale.

Do najświetniejszych ówczesnych puławskich żywych obrazów należały prezentacje na cześć księcia Józefa Poniatowskiego ${ }^{112}$. W niekompletnie zachowanych I.... sposób odgadywania treści żjych obrazów do szarad. Zob. też Ra tajczak owa, Galeria gatunkóv widowiskowych, s. 279-283.

111 Zob. Dziechcińska, op. cit., s. 32-34. - M. Ko mza, Żywe obrazy. Między scena, obrazem i książka. Wrocław 1995, s. 112-123. - Ra taj c zakow a, Galeria gatunków widowiskowych, s. 279-280.

112 Zob. Aleks a nd row i c z, Izabela Czartoryska, s. 109-110. - Ra t a j c za k ow a, Galeria gatunków widowiskowych, s. 283. 
odręcznych notatkach księcia Adama Kazimierza, zatytułowanych Opisanie Tableau $w$ niedzielę dnia 31 stycznia $1819 w$ Sieniawie, czytamy o sześciu tableaux vivants zaprezentowanych w karnawałową niedziele „po balu migdałowym” ${ }^{113}$. Jest to informacja zarówno o znakomitych osobach w grupach obrazowych, jak i o artystach malarzach, których dzieła odtwarzano. Ich autorami byli Pierre Guérin, Annibale Carracci i Rafael Santi. W najpiękniejszym $z$ owych żywych obrazów wystapiła Izabela - ,jako Jutrzenka”"114, przepasana girlandą róż. Tematyka narodowa została utrwalona w obrazie trzecim, replikującym ilustrację okładkową Śpiewów historycznych Niemcewicza.

Funkcję edukacyjną żywych obrazów wspomina też wnuk Izabeli - Władysław Czartoryski:

urządzała moja babka częste zabawy, złożone nie tylko z tańców i gier, ale i z przedstawień teatralnych, z żywych obrazów itp., do których zawsze przedmioty z życia narodowego wybierano [...].

\section{I dalej relacjonuje:}

Pewnego razu miano dać żywy obraz przedstawiający wjazd Marii Ludwiki do Gdańska. Ustawiono właśnie figurantów na scenie. W tej chwili wchodzi do pokojów stary szlachcic, przybyły z głębokiej Rusi za ważnym prywatnym interesem. Spotyka go księżna Wirtemberska, a widząc postać w odświętnym stroju, bierze go za jednego z aktorów i posuwając go mówi: „Prędzej, prędzej, idź W[ać] Pan do sali, gdzie już wszyscy czekają" O niczym naturalne nie wiedząc, oszołomiony przybysz znajduje się niechcący w grupie ustawionej. Co chce przemówić lub poruszyć się, wszyscy wołają: „cicho, cicho”. Skończyło się przedstawienie. Szlachcic nie szukając nawet wytłumaczenia, co to wszystko ma znaczyć, co tchu uciekł i dopiero $\mathrm{z}$ pierwszego popasu napisał, o co mu chodziło ${ }^{115}$.

Wspomnienie wnuka księżnej rejestruje ważną cechę żywych obrazów, jaką jest możliwość przechodzenia ze wspólnoty nieprofesjonalnych widzów do grupy niekoniecznie profesjonalnych wykonawców. Stary szlachcic w obu grupach pozostał sobą i z perspektywy tej postaci żywy obraz staje się teatralizacją, zachowująca funkcję przekazywania i upowszechniania treści o charakterze patriotycznym.

Izabela Czartoryska stworzyła w Puławach multimedialny ośrodek pamięci narodowej, w intencji udostępnienia oraz upowszechnienia treści wolnościowych i patriotycznych. O wielogłosowości projektu stanowiła suma mediów kumulujących owe treści: Świątynia Sybilli, Domek Gotycki, teatr, park-ogród, biblioteka, galeria obrazów, zacisza poetów. Każdy z tych elementów funkcjonuje także jako odrębna platforma historycznego i patriotycznego przekazu. Zarazem po wystawieniu opery Kniaźnina Matka Spartanka prywatny teatr dworski w Puławach przeszedł do sfery publicznej ${ }^{116}$. Wcześniejsze formy teatru dworskiego, którego przykładem może być teatr poprzedniczki Izabeli Czartoryskiej - księżnej Franciszki Urszuli Radziwiłłowej w Nieświeżu - zostają w Puławach zastąione programem otwartym. Puławskie realizacje multimedialne, budujące historyczną rangę tego ośrodka kultu-

A. K. Czartoryski, Opisanie Tableau w niedziele dnia 31 stycznia 1819 w Sieniawie. Bibl. Czartoryskich, rkps 6011 IV t. 7: 1776-1819, k. 9.

115 W. C zart ory s ki, Losy zbiorów Czartoryskich. Cyt. za: Pezda, op. cit., s. 112-127.

116 Zob. B. Judkowiak, Wzgardzony wielogłos. Kultura teatralna czasów saskich i jej tradycje. Poznań 2007, s. 214-220. 
ry rodzimej, były rezultatem przedstawionego w tym artykule procesu rozwoju osobowości artystyczno-teatralno-patriotycznej księżnej Czartoryskiej i utrwalone zostały przez kontynuatorów tych tradycji ${ }^{117}$. Izabela Czartoryska swą biografia i osiągnięciami stworzyła w Wieku Świateł nowy i nowoczesny obraz kobiety z kręgów kultury wysokiej ${ }^{118}$.

\section{Abstract \\ IRENA KADULSKA University of Gdańsk \\ GRAND LADY OF THE ENLIGHTENMENT PRINCESS IZABELA CZARTORYSKA IN THE LIGHT OF THEATRE, THEATRICALISATION, AND MEDIA}

The article discusses the theatre, acting, and educational activity of Izabela Czartoryska, née Flemming, the wife of Adam Kazimierz Czartoryski-a dramatist of the Enlightenment and a theorist. A panegyric dedicated to her on November $19^{\text {th }}, 1765$, during The National Theatre opening ceremony, made her the patroness of the Polish stage. As based on authoritative sources, the paper depicts her acting on stage, presence among the Polish and foreign theatre audience, planning of the programme, inspiration of dramatists, education of actors of School of Chivalry and of The National Theatre. The text also focuses of Izabela's stage acting profile and traces her relation with the audience. In conclusion it is stated that all forms of Czartoryska's early acting experience formed a basis for her creation in the family residence of Puławy a centre of national culture.

117 Zob. wybrane przykłady poetyckiej kontynuacji Matki Spartanki przedstawione w pracy P. Matuszewskiej Twierdze i oazy. Obraz Kresów w poezji polskiego oświecenia (w zb.: W kręgu oświecenia i teatru. Profesorowi Mieczysławowi Klimowiczowi w 70 rocznicę urodzin. Red. A. C i eńs ki. Wrocław 1989). Zob. też M. C h a c h a j, Dramy i tragedie historyczne Juliana Ursyna Niemcewicza. Lublin 2007, s. 106-108. Pochwałe deklamacyjnego aktorstwa Czartoryskiej w Matce Spartance znajdujemy w wierszach J. U. Niemcewicza, J. Koblańskiego i poetów anonimowych, zamieszczonych bezpośrednio po tekście opery w tomie F. D. Kn i aźn in a Utwory dramatyczne. Wybór (Oprac. A. J en dry si k. Warszawa 1958, s. 96-99).

118 Zob. G. B or k ow s ka, ...mówienie o literaturze. W zb.: Beatrycze $i$ inne. Mity kobiet $w$ literaturze i kulturze. Red. G. B or kow ska, L. Wiśn ni ew ska. Gdańsk 2010, s. 6. - Ko s tki ew i czowa, Osiemnastowieczne projekty antropologiczne: od oświecenia ku długiemu trwaniu. 